\title{
青年におけるナルシシズム（自己愛）的傾向と 親の養育態度・家庭の雰囲気との関係
}

\author{
宮下一博*
}

\section{A STUDY ON NARCISSISTIC PERSONALITY TRAITS OF ADOLESCENTS}

\author{
Kazuhiro Miyashita
}

\begin{abstract}
The purposes of the present paper were to examine the relations of narcissistic personality to Ss' present recollections concerning their parents' earlier attitudes and home environment. The Narcissistic Personality Inventory (NPI) revised by Miyashita and Kamiji (1985), and three other questionnaires measuring mother's and father's attitudes together with the home environment were administered to 270 college students. Correlations were performed between NPI scores and the other three measures. The results showed that in case of females, a significant negative correlation was found between narcissism and the emotional acceptance of the mother : such result supported the theory of narcissism. In the case of male subjects a significant positive correlation was found between narcissism and the father's dominating attitude. With such a result, it was suggested that the father could not be neglected in the theory of narcissism.
\end{abstract}

Key words : Narcissistic Personality Inventory, mother's and father's attitudes, acceptance of mother.

\section{問題と目的}

ナルシシズム (自己愛)に関する研究は，従来は主と して精神分析学的観点からの理論的研究がその中心で あった。古くは，Freud (1914) などが，また近年で は, Kernberg $(1975,1980)$, Kohut $(1971,1976)$ らが, いわゆるナルシシズムの病理を中心に，その理論構築 や臨床実践を行ってきた。こうした研究の紹介は, 宮 下・上地 (1985) や中西・佐方 (1986) に譲るが, ナルシ シズムの概念を明確にすべく多くの研究が積み重ねら れてきた。その一方で,「ナルシシズム」というものを 心理検査や質問紙により実証的に捉えようとする研究 も盛んになりつつあり，心理検査の代表として，ロー ルシャッハ・テスト (Exner, 1969 ; Harder, 1979など) や

* 千葉大学 (Chiba University)
TAT (Grayden, 1958 ; Harder, 1979 など) も利用され始め た。また, Raskin \& Hall(1979)による NPI(Narcissistic Personality Inventory) の発表は，ナルシシズムの測定的 研究を助長させ, 正常人をも対象とする数多くの実証 的研究を生み出す 1 つの契機となった。幾つか例を挙 げても, Emmons (1981, 1984, 1987), Auerbach (1984), Joubert (1986), Raskin \& Terry (1988), Raskin \& Novacek (1989) など, その研究の数だけを見ても重要 な研究の 1 つとして位置づけられる。

我国においてもこの NPI に刺激されたかたちで幾 つかの研究が登場するようになった。宮下・上地 (1985), 大石 $(1987,1988,1989)$, 佐方 $(1987,1988)$, 大平 $(1988,1989)$ などがそれである。これらの研究は, NPI の信頼性や妥当性の検討を始め, 共感性や不安, 種々 の性格検査との関連を検討することにより自己愛的人 格**の特徵を明確にしようとする研究である。このよ 
うな研究の中で, NPI は少しずつ姿を変えてきている (例えば, 宮下・上地（1985）では, Raskin \& Hall（1979）の二 者択一法を 7 段階評定に, 佐方 (1986) では 5 件法にそれぞれ回答 方法を修正している)とはいえ，今やNPI は，青年期にお ける自己愛的人格を研究する上で，欠くことのできな い 1 つの測定具になるに至った。

ところで, Kernberg (1975) は, 病理的なナルシシズ ムの特徵として, 過度の自己陶酔, 強烈な野心, 誇大 な空想，賞賛に対する過剩依存，栄光や権力・美を求 める絶え間ない欲望などを挙げている。そして，こう した特徵は, 愛する能力の欠如, 共感性の欠如, 慢性 的な空虚感，他者に対する搾取などのかたちで顕在化 すると述べている。これまでの NPI を用いた様々の研 究から, 自己愛的人格傾向の強い者ほど，エネルギッ シュで外向的，自信家，自己本位，競争的，攻撃的で あり，共感性に乏しいことなどが明らかにされている が,これらは, 先の Kernberg の述べる特徵とよく符合 するように思われる。一方，Kernberg (1975) は，この ようなナルシシズムが生まれる要因として，幼少期に 冷淡で共感性のない母親によって情緒的な飢餓状態に 置かれたことを指摘している。この点については, Kohut（1971）もほほ同様の指摘を行っている。

このように，ナルシシズムの原因については，ある 1 つの視点から明確な指摘がなされているにもかかわ らず，この点に焦点を当てた実証的研究はほとんど見 られないのが実態である。このことは，「幼少期」の定 義の曖昧さもさることながら, その測定の難しさも 1 つの要因になっているのであろう。

そこで，本研究では，探索的にこの点に焦点を当て てみたいと思う。この点を検討する方法としては, 次 の 2 つを考えることができる。その第 1 は，青年の母 親に，子どもの幼少期における関わり方を回想しても らうこと, 第 2 は，青年自身に母親の自分に対する態 度を回想して自己報告してもらうことである。この前 者の方法については, 現在, 研究を進めている最中で あり，次報以降に取り扱う予定である。さて，本研究 では，後者の方法により研究を行うが，青年に自己の 幼少期の母親を回想させるというのはかなりの困難が 伴う。ナルシシズムの理論で定義される「幼少期」と いうものは，せいぜい $2 \sim 3$ 歳頃であり，その時期ま

** 質問紙を利用した自己愛ないし自己愛的人格の研究では, 病 理的なナルシシズムも正常範囲のそれも連続線上のものとし て扱わざるを得ない。つまり, 質問紙研究では, その人格の程 度を問題にしていくのであり，本稿では，「自己愛的人格傾向」 という言葉も数多く用いている。
で遡るのはかなり難しいと言わざるを得ない。そこで, 本研究では，これまでの母親の養育態度を包括的に回 想してもらうという方法をとった。本研究で扱うのは, その多くが正常青年であることを考えれば，母親の責 育態度に幼少期からの一貫性を想定することは，それ ほど無理はないように思われる（但し，この点については， 後の研究により実証的に確認される必要がある)。また, 本研究 では，母親の養育態度以外に，父親の養育態度ならび に家庭の雲囲気についても取り挙げた。ナルシシズム の理論では，母親が強調されているが，父親をも含め た家族全体の存在というものも当然考察されるべきで あろう。

以上の問題意識に基づき，本研究では，青年の自己 愛的人格傾向と母親, 父親の養育態度, 家庭の雾囲気 との関係を検討することを目的とした。

\section{方法}

被験者 国立 C大学 3 年生 (青年心理学受講生), 男子 110名，女子160名（いずれも有効数）の合計 270 名。

質問紙 (1) NPI*** (Raskin \& Hall, 1979 をもとに宮下・ 上地, 1985 が作成した 35 項目。なお,これらには 34 のダミー項目 が加えられランダムに配㯰されている。7 段階評定)

(2)母親・父親の養育態度を測定する質問紙 (Schaefer, 1965 を参考に筆者が作成した, TABLE 1 に示す 30 の項目対。母・ 父別に評定。7段階評定）。

TABLE 1 母・父の養育態度を測定する項目

\begin{tabular}{r|l||r|l}
\hline NN. & \multicolumn{1}{|c|}{ 項 } & No. & \multicolumn{1}{|c}{ 項 } \\
\hline 1 & 自律性を尊重する一尊重しない & 16 & 無視する一重視する \\
2 & 開放的な一閉鎖的な & 17 & いい加減な一きちんとした \\
3 & 肯定的な一否定的な & 18 & 公平な一不公平な \\
4 & 意欲的な一無気力な & 19 & やさしい一冷たい \\
5 & でしゃばりな一謙虚な & 20 & 拘束的な一解放的な \\
6 & 口うるさい一もの静かな & 21 & 意地の悪い一お人よしの \\
7 & いらいらした一落着いた & 22 & 厳しい一甘い \\
8 & 無関心な一熱心な & 23 & 感情的な一理性的な \\
9 & 信頼する一信頼しない & 24 & ばらばらな一一貫した \\
10 & 個性を尊重する一尊重しない & 25 & 平等な一不平等な \\
11 & 支持的な一支持的でない & 26 & にこやかな一無表情な \\
12 & 子供中心の一大人中心の & 27 & 保護的な一自由な \\
13 & 指示的な一非指示的な & 28 & 統制的な一非統制的な \\
14 & こせこせした一おうような & 29 & しつこい一さっぱりした \\
15 & 安定した一不安定な & 30 & 拒否的な一受容的な \\
\hline
\end{tabular}

*** Raskin \& Hall (1979) の原法をかなり修正したが，同様に NPI という名称を用いた。その作成の手続については, 宮下. 上地（1985）を参照のこと。 
(3)家庭の雰囲気を測定する質問紙 (長島ら,1967による 47 項目の形容詞対。7 段階評定)。

なお，上記の (2)，(3) の項目は，宮下・小林（1984） においても利用され一応の構造化がなされているが, その時の被験者数の制限に基づく因子構造の不安定性 なども考慮し, 本研究では, 再度それらの構造につい ての分析も行った。

実施方法 上述の 3 種の質問紙を授業時間を利用し て集団的に実施した。その際，「甘親・父親の養育態度」 や「家庭の雾囲気」については，自分の生活史を振り 返り総合的に回答するよう教示を行った。

実施時期 1989年 4 月中旬及び10月初旬。

\section{結果の処理法}

(1) NPI の処理法：NPI を構成する35項目について, 自己愛的傾向が強いほど高得点となるようにそれぞれ 7 〜 点を付与し, 総得点を算出した。

(2)母親・父親の養育態度を測定する質問紙の処理 法：TABLE 1 に示す項目対について, 左側の傾向が強 いほど高得点となるよう各項目に 7 〜点を付与し， 父親，母親別に主因子解による因子分析を行った。そ して, 父親, 母親とも固有值 2.0 以上の 3 因子を抽出 し，これにヴァリマックス回転を施した。1つの因子 にのみ絶対值. 40 以上の負荷を有することを条件に, 単 純構造をなす項目の選択を行い, 結果の概要を, TABLE 2 と TABLE 3 に示した。それに基づいて, 各因 子の解釈を行うと，まず，母親の養育態度 (TABLE 2) については，第 1 因子（F1）は，「情緒的支持・受容」， 第 2 因子（F2）は，「情緒不安定」，第 3 因子（F3）は, 「支配・介入」, 次に, 父親の養育態度 (TABLE 3) では, F1は，「情緒的支持・受容」，F2は，「情緒不安定」，F3 は，「支配・介入」とそれぞれ命名された。なお，寄与 率の合計は，母親，父親それぞれ $51.34 \% ， 56.15 \%$ で あり，分散の説明率は十分であろうと思われる。

以下, 母親, 父親ごとに, 各因子とも単純構造をな す項目の総得点を算出した。

(3)家庭の雾囲気を測定する質問紙の処理法：「母 親・父親の養育態度」を測定する質問紙と同様に，各 項目に $7 \sim 1$ 点を付与し, 主因子解による因子分析を 行い, 固有値 2.0 を基準に 3 因子を抽出, これにヴァリ マックス回転を施した。1つの因子にのみ絶対值.40以 上の因子負荷を有することを条件に，単純構造をなす 項目を整理したものが，TABLE 4 である。それによれ ば，F1は，「冷淡・厳格」，F2は，「不誠実・無秩序」， F3は, 「内閉・謙虚」とそれぞれ解釈され, 各々単純構 造をなす項目の総得点を算出した。なお，3因子によ
TABLE 2 母親の養育態度を測定する項目の因子構造

\begin{tabular}{|c|c|c|c|c|}
\hline 項 & $\mathrm{F} 1$ & $\mathrm{~F} 2$ & F3 & $h^{2}$ \\
\hline 公平な一不公平な & .716 & -.342 & -.106 & .641 \\
\hline 無視する一重視する & -.710 & -.100 & .008 & .514 \\
\hline やさしい一冷たい & .700 & -.218 & -.175 & .569 \\
\hline 平等な一不平等な & .676 & -.326 & -.074 & .569 \\
\hline にこやかな一無表情な & .665 & -.168 & -.144 & .492 \\
\hline 支持的な一支持的でない & .655 & -.113 & -.287 & .524 \\
\hline いい加減な一きちんとした & -.633 & .245 & -.319 & .567 \\
\hline 信頼する一信頼し & .628 & $\cdots .089$ & -.352 & .526 \\
\hline 的な一無気力な & .615 & .329 & -.050 & .489 \\
\hline 否的な一受容的な & -.609 & .128 & .264 & .457 \\
\hline の悪いーお人ょしの & -.553 & .243 & .182 & .398 \\
\hline 子供中心の一大人中心の & .455 & -.135 & -.210 & .270 \\
\hline こせこせした一おうような & -.419 & .371 & .396 & .471 \\
\hline ばりな & 048 & .774 & .293 & .687 \\
\hline 感情的な一理性的な & -.167 & .757 & .136 & .620 \\
\hline 口うるさい一もの & .007 & .751 & .275 & .640 \\
\hline いらいらした一落着いた & -.338 & .676 & .202 & .613 \\
\hline しつこいーさっぱりした & -.297 & .509 & .348 & .469 \\
\hline 拘束的な一解方 & -.247 & .219 & .741 & .658 \\
\hline 統制的な一非統制的な & -.011 & .162 & .690 & .502 \\
\hline 自律性を尊重する一尊重 & .290 & -.244 & -.665 & .586 \\
\hline 開放的な一閉鎖的な & .372 & .077 & -.647 & .563 \\
\hline 指示的な一非指示的な & .194 & .310 & .524 & .408 \\
\hline 保護的な一自由な & .023 & .329 & .522 & .382 \\
\hline 厳しい一甘い & -.118 & .048 & .464 & .231 \\
\hline 寄与率（\%） & 22.54 & 14.11 & 14.69 & 51.34 \\
\hline
\end{tabular}

TABLE 3 父親の養育態度を測定する項目の因子構造

\begin{tabular}{|c|c|c|c|c|}
\hline 項 & F1 & $\mathrm{F} 2$ & $\mathrm{~F} 3$ & $h^{2}$ \\
\hline やさしい一冷たい & .751 & -.343 & .022 & .682 \\
\hline 無視する一重視する & -.695 & .160 & -.240 & .566 \\
\hline 意欲的な一無気力な & .694 & -.061 & .326 & .591 \\
\hline にこやかな一無表情な & .677 & -.081 & -.019 & .466 \\
\hline 支持的な一支持的でない & .648 & -.227 & -.280 & .550 \\
\hline 拒否的な一受容的な & -.633 & .266 & .254 & .536 \\
\hline 信頼する一信頼しない & 625 & -.327 & -.252 & .561 \\
\hline 意地の悪い一お人よしの & -.606 & .336 & .195 & .518 \\
\hline 子供中心の一大人中心の & .570 & -.141 & -.233 & .399 \\
\hline 肯定的な一否定的な & .554 & -.305 & -.391 & .552 \\
\hline 個性を尊重する一尊重しない & .552 & -.385 & -.283 & .533 \\
\hline 自律性を尊重する一尊重しない & .439 & -.350 & -.393 & .470 \\
\hline 感情的な一理性的な & -.067 & .791 & .081 & .636 \\
\hline ばらばらな一一貫した & -.255 & .772 & -.139 & .681 \\
\hline いらいらした一落着いた & -.272 & .761 & .250 & .716 \\
\hline 安定した一不安定な & .395 & -.627 & -.149 & .572 \\
\hline 統制的な一非統制的な & -.119 & .060 & .790 & .642 \\
\hline 拘束的な一解放的な & -.298 & .165 & .765 & .702 \\
\hline 保護的な一自由な & -.022 & .053 & .660 & .439 \\
\hline 指示的な一非指示的な & -.004 & .229 & .604 & .418 \\
\hline 寄与率（\%） & 25.49 & 15.80 & 14.86 & 56.15 \\
\hline
\end{tabular}


る寄与率の合計は $47.05 \%$ であり,十分な値と判断され た。

\section{結果と考察}

NPI 得点と「母親の養育態度」,「父親の養育態度」, 「家庭の雾囲気」のそれぞれ 3 つの「単純構造をなす項 目の総得点」との相関係数を男女別に算出し, TABLE 5 に示した。

\section{1. 自己愛的人格と母親の養育態度}

TABLE 5 より，女子においてのみ，「情緒的支持・受 容」の因子とは負の, また, 「情緒不安定」の因子とは 正のそれぞれ有意な相関が見られた。これらの結果は，

TABLE 4 家庭の雲囲気を測定する項目の因子構造

\begin{tabular}{|c|c|c|c|c|}
\hline 項 & $\mathrm{F} 1$ & $\mathrm{~F} 2$ & F3 & $h^{2}$ \\
\hline 角のある一丸い & .786 & .061 & .167 & .650 \\
\hline おだやかな一激しい & -.744 & -.062 & .173 & .587 \\
\hline 暖かい一冷たい & -.742 & -.255 & -.239 & .672 \\
\hline 自分勝手な一思いやりのある & .685 & .345 & .085 & .595 \\
\hline 気持良い一気持悪い & -.680 & -.278 & -.367 & .675 \\
\hline 㛜しい一やさしい & .665 & -.175 & -.006 & .472 \\
\hline 素直な一強情な & -.637 & -.122 & -.137 & .440 \\
\hline 短気な一気長な & .623 & .149 & -.015 & .410 \\
\hline 感情的な一理性的な & .517 & .177 & -.223 & .349 \\
\hline 信じ易い一懐疑的な & -.462 & .061 & -.239 & .275 \\
\hline かたいーやわらかい & .462 & -.369 & .349 & .471 \\
\hline 不注意な一注意深い & .060 & .762 & -.074 & .590 \\
\hline きちんとしたーだらしのない & -.275 & -.738 & .042 & .623 \\
\hline まじめな一ふまじめな & -.052 & -.709 & .150 & .527 \\
\hline 慎重な一軽率な & -.220 & -.707 & .133 & .566 \\
\hline 勤勉な一怠惰な & .084 & -.691 & -.113 & .497 \\
\hline 無能な一有能な & .224 & .640 & .284 & .540 \\
\hline 不正確な一正確な & .223 & .596 & .050 & .407 \\
\hline 不潔な一清潔な & .254 & .573 & .109 & .405 \\
\hline 物覚えのよい一忘れっぼい & -.002 & -.414 & -.078 & .177 \\
\hline 外向的な一内向的な & -.289 & -.096 & -.710 & .597 \\
\hline 孤独な一社交的な & .385 & .145 & .658 & .601 \\
\hline ひかえめなーでしゃばりな & -.169 & -.164 & .647 & .474 \\
\hline 無口な一おしゃべりな & .350 & .055 & .646 & .543 \\
\hline 個性のない一個性的な & -.083 & .093 & .614 & .393 \\
\hline 小心な一大胆な & .022 & .279 & .548 & .379 \\
\hline 臆病な一勇敢な & .116 & .361 & .528 & .422 \\
\hline 冷静な一情熱的な & -.003 & -.103 & .519 & .280 \\
\hline 派手な一地味な & .087 & .181 & -.511 & .301 \\
\hline 内面的な一外面的な & .056 & -.130 & .415 & .192 \\
\hline 寄与率 (\%) & 17.67 & 15.72 & 13.66 & 47.05 \\
\hline
\end{tabular}

TABLE 5 NPI 得点と「母親・父親の養育態度」及び「家 庭の䨌囲気」との関係

\begin{tabular}{|c|c|c|c|}
\hline & & 男（N=110） & 女 $(\mathrm{N}=160)$ \\
\hline 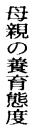 & $\begin{array}{l}\text { F1(情緒的支持・受容) } \\
\text { F2（情緒不安定） } \\
\text { F3(支配・介入) }\end{array}$ & $\begin{array}{r}-.055 \\
-.005 \\
.126\end{array}$ & $\begin{array}{l}-.165^{*} \\
.157^{*} \\
-.093\end{array}$ \\
\hline 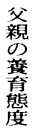 & $\begin{array}{l}\text { F1 (情緒的支持・受容) } \\
\text { F2（情緒不安定） } \\
\text { F3(支配・介入) }\end{array}$ & $\begin{array}{c}-.135 \\
.046 \\
.201^{*}\end{array}$ & $\begin{array}{r}.134^{+} \\
-.076 \\
.061\end{array}$ \\
\hline $\begin{array}{l}\text { 家 } \\
\text { 庭 } \\
\text { 鰵 } \\
\text { 気 }\end{array}$ & $\begin{array}{l}\text { F1 (冷淡・厳格) } \\
\text { F2 (不誠実・無秩序) } \\
\text { F3(内閉・謙虚) }\end{array}$ & $\begin{array}{r}.077 \\
-.174^{+} \\
-.164^{+}\end{array}$ & $\begin{array}{c}.163^{*} \\
-.092 \\
-.216^{* *}\end{array}$ \\
\hline
\end{tabular}

これまでの理論的研究の枠組みをほほ実証的に検証す る結果と言えよう。即ち，女子の場合，母親の暖かい 受容的態度が自己愛的傾向を抑制するかたちで，また， 感情的であったり情緒不安定であるような，いわゆる 否定的な養育態度はこれを増長させると考えうる結果 が得られた。男子において，有意な関連が認められな かったのは，自己愛的人格の形成における性差を示す ものかも知れない。これまでの自己愛的人格の研究で は,このような性差については殁ど検討されておらず, 今後, さらに研究を続ける中で徐々に結論が下される であろう。

\section{2.自己愛的人格と父親の養育態度}

TABLE 5 によれば, 男子では第 3 因子, 即ち,「支配・ 介入」の養育態度と自己愛的人格得点との間に正の有 意な相関が得られた。また，女子においては，「情緒的 支持・受容」の因子との間に正の有意な傾向が認めら れた。つまり，男子では，幼少期からの父親の養育態 度が支配・介入的と認知するほど，女子では，暖かく 受容的であると認知するほど，自己愛的人格得点が有 意に高い（あるいはその傾向）という結果が得られた。こ のうち，女子の結果は若干意外な結果ともいえるが, 男子では，ある意味で予想される結果が得られた。

これまでの自己愛に関する理論的研究では，母親が 強調されてきたが，父親との関係も無視できない部分 があろう。本研究の結果では, 父親の支配・介入とい うある種の否定的な養育態度は, 男子においてのみ有 意な関連が認められた。女子においては, 男子に比べ, 自己愛的人格傾向に及ほす父親の影響は弱いといえる が，情緒的支持・受容の養育態度が自己愛的傾向と正 の関係 (傾向) が認められたことは興味が持たれる点で 
ある。先の母親の結果をも合わせて考えると，女子で は, 受容的な母親は自己愛的傾向を抑制するものの, 父親のそうした傾向は，むしろそれを促進させるとい うことになる。

全体的に考えれば，自己愛的人格との関係において は，男子では父親の否定的な養育態度が，女子では母 親のそうした態度が強い関連を有するといってよいか も知れない。このような結果は，一部理論的に妥当な ものといえようが, 父親については未知の点が残され ており, 今後さらに研究の蓄積が必要であろう。

\section{3. 自己愛的人格と家庭の雾囲気}

TABLE 5 の家庭の雲囲気について見ると, 男子では, 第 2 , 第 3 因子, 即 $5, 「$ 不誠実 - 無秩序」,「内閉・謙 虚」とそれぞれ負の有意な傾向が認められた。また， 女子では，第 1 因子（冷淡・緟格の因子）とは正の，第 3 因子 (内閉·謙虚の因子) とは負のそれぞれ有意な相関が 得られた。

男女とも，「内閉・謙虚」の因子と負の有意な相関(あ るいは傾向）が認められたが，これは逆に言えば，自己 愛的人格傾向の高い者の家庭のあり方として，外向的 で活発，大胆，派手などの特徵を読みとることができ， これらは自己愛的人格そのものの特徵ともかなりの点 で一致するものであろう。また, 女子において,「冷淡・ 厳格」の因子と正の有意な相関が得られたことは, 家 庭全体のあり方についても，冷ややかで厳格な家庭と いうものが自己愛的人格傾向を助長させる（あるいは生 み出す）ことを示しており，自己愛的人格の背景とし て，単に母親のみならず，父親をも含めた家庭全体を 問題にする必要があることを示唆しているようにも思 われる。

\section{引用文献}

Auerbach, J.S. 1984 Validation of two scales for narcissistic personality disorder. 'Journal of Personality Assessment, 48, 649-653.

Emmons, R.A. 1981 Relationship between narcissism and sensation-seeking. Psychological Reports, 48, 247-250.

Emmons, R.A. 1984 Factor analysis and construct validity of the Narcissistic Personality Inventory. Journal of Personality Assessment, 48, 291-300.

Emmons, R.A. 1987 Narcissism : Theory and measurement. Journal of Personality and Social Psychology, 52, 11-17.
Exner, J.E. 1969 Rorschach responses as an index of narcissism. Journal of Personality Assessment, 33, 324-330.

Freud, S. 1957 On narcissism : An introduction. In J. Strachey (Ed. and Trans.), The standard edition of the complete psychological works of Sigmund Freud (Vol. 14, Pp. 73-102). London : Hogarth Press. (Original work published 1914)

Grayden, C. 1958 The relationship between neurotic hypochondriasis and three personality variables : Feeling of being unloved, narcissism, and guilt feelings. Dissertation Abstracts International, 18, 2209-2210.

Harder, D.W. 1979 The assessment of ambitious narcissistic character style with three projective tests : The early memories, TAT, and Rorshach. Journal of Personality Assessment, 43, 23-32.

Joubert, C.C. 1986 Social interest, loneliness, and narcissism. Psychological Reports, 58, 870.

Kernberg, O. 1975 Borderline conditions and pathological narcissism. New York : Jason Aronson.

Kernberg, O. 1980 Internal world and external reality. New York : Jason Aronson.

Kohut, H. 1971 The analysis of the self. New York : International Universities Press.

Kohut, H. 1976 The restoration of the self. New York : International Universities Press.

宮下一博・上地雄一郎 1985 青年におけるナルシシ ズム (自己愛) 的傾向に関する実証的研究(1) 総 合保健科学, 1, 51-61.

宮下一博・小林利宣 1984 疎外感と幼少期の家庭環 境及び自己概念との関係 広島大学教育学部紀 要, 33, 141-147.

長島貞夫・藤原喜悦 - 原野広太郎・斉藤耕二・堀洋道 1967 自我と適応の関係についての研究(2)-Self -Differential の作製一 東京教育大学教育学部 紀要, 14, 59-83.

中西信男・佐方哲彦 1986 ナルシズム時代の人間学 福村出版

大平英樹 1988 自己愛人格と不安の関係一自己愛人 格目録 (NPI) の検討一 日本心理学会第52回大会 発表論文集, 110 . 
大平英樹 1989 自己愛人格における怒りの感情と攻 撃的行動 一生理的喚起の促進作用に着目して一 日本心理学会第53回大会発表論文集, 154.

大石史博 1987 ナルシシズム的人格に関する研究(2)

-YG 性格検査との関係について一- 日本心理学 会第51回大会発表論文集, 535 .

大石史博 1988 ナルシシズム的人格に関する研究(3)

--CMI, MMPI との関係について一－日本心理学 会第52回大会発表論文集, 109.

大石史博 1989 ナルシシズム的人格に関する研究(4)

一共感性との関係について一 日本心理学会第53

回大会発表論文集, 155.

Raskin, R., \& Hall, C.S. 1979 A narcissistic personality inventory. Psychological Reports, 45, 590.

Raskin, R., \& Novacek, J. 1989 An MMPI description of the narcissistic personality. Journal of Personality Assessment, 53, 66-80.

Raskin, R., \& Terry, H. 1988 A principal compo- nents analysis of the Narcissistic Personality Inventory and future evidence of its construct validity. Journal of Personality and Social Psychology, 54, 890-902.

佐方哲彦 1986 自己愛人格の心理測定 一自己愛人 格目録 (NPI) の開発一 和歌山県立医科大学進学 課程紀要, 16, 77-86.

佐方哲彦 1987 自己愛人格目録 (NPI)の妥当性に関 する研究 $-\mathrm{Y}-\mathrm{G}$ 検査および MPI，MMPI との 相関から一 日本教育心理学会第29回総会発表論 文集, $538-539$.

佐方哲彦 1988 同一性拡散の心理的特徵の一側面 一自己愛傾向および共感性との関連一 日本心理 学会第52回大会発表論文集, 108.

Schaefer, E.S. 1965 Children's report of parental behavior : An inventory. Child Development, 36, 413-424.

（1991年 5 月27日受稿） 